\begin{tabular}{c}
\hline Review of \\
ECONOMICS \\
and \\
INSTITUTIONS
\end{tabular}

\title{
Estimating the Effect of Transitory Economic Shocks on Civil Conflict
}

\author{
Antonio Ciccone ${ }^{凶}$ \\ Mannheim University
}

\begin{abstract}
Economists and political scientists have argued that differences in the risk of civil conflict across countries and over time may partly reflect differences in the opportunity cost of participating in civil conflicts. One way to test for the opportunity-cost channel is to examine civil conflict risk following transitory income shocks. In this paper I propose two instrumentalvariables approaches to estimate the effect of transitory income shocks on civil conflict risk. I also show that approaches not tailored to transitory income shocks may lead to the conclusion that negative income shocks increase the risk of civil conflict - which would seem consistent with an opportunity-cost channel - when they actually lower civil conflict risk. I illustrate these issues by revisiting Miguel, Satyanath, and Sergenti's (2004) conclusion that negative income shocks increase the risk of civil conflict in Subsaharan Africa.
\end{abstract}

JEL classification: D74; E32; 011; 017; O47

Keywords: transitory economic shocks, conflict, weather

I gratefully acknowledge research support from CREI, Spanish research grant ECO220115272, and Spanish research grant SEV-2011-0075 (Severo Ochoa Program for Centers of Excellence in R\&D).

Mannheim University, L7, 3-5, 68131 Mannheim, Germany. (Phone: 0621/1811773, Fax: 0621/1811774. antonio.ciccone@gmail.com).

\section{Recommended Citation}

Ciccone, A. (2013). Estimating the Effect of Transitory Economic Shocks on Civil Conflict. Review of Economics and Institutions, 4(2), Article 1. doi: 10.5202/rei.v4i2.126. Retrieved from http://www.rei.unipg.it/rei/article/view/126 


\section{Introduction}

Political scientists, economists, and climate-change researchers have recently been investigating the effect of weather and weather-driven economic changes on the risk of civil conflict (e.g. Miguel et al. 2004; Burke et al. 2009; Buhaug, 2010; Ciccone, 2011; Hsiang et al. 2011). One of the main empirical issues is whether civil conflict risk is related to weather shocks - unpredictable deviations from normal (average) weather - and weather-induced income shocks. This question is of special interest in economics and political sciences where it has been argued that differences in the risk of civil conflict across countries and over time may be partly driven by differences in the opportunity cost of participating in civil conflicts (e.g. Collier and Hoeffler, 1998; Fearon and Laitin, 2003; Miguel et al. 2004). In many underdeveloped economies, the opportunity cost of participating in civil conflicts mainly consists of foregone agricultural production and agricultural productivity depends on weather. By examining the effect of weather shocks and weather-induced income shocks on civil conflict risk, we may therefore learn if civil conflict is partly driven by the opportunity cost of participation.

In theory, differences in the opportunity cost of participating in civil conflicts should translate into differences in civil conflict risk as they change the cost relative to the prize of fighting (e.g. Fearon, 2007; Chassang and Miquel, 2009). A difficulty faced by empirical researchers wanting to test for the opportunity-cost channel is that the prize of fighting is generally unobservable and will often move in the same direction as the opportunity cost. For example, in low-productivity countries both the opportunity cost of fighting and the prize should be lower than in high-productivity countries. Hence, as emphasized by Fearon (2007), the opportunity-cost argument does not imply that civil conflict should be more prevalent in low-productivity countries. For similar reasons, it is hard to test for the opportunity-cost effect by examining civil conflict risk following adverse economic shocks. Many shocks have long-lasting economic effects and will therefore affect the prize of participating in a civil conflict as well as the opportunity cost.

As made clear by Chassang and Miquel's (2009) theoretical analysis, one way to test for the opportunity-cost effect is to examine civil conflict risk following (transitory) income shocks that affect contemporaneous but not long-run productivity. Such shocks should change the opportunity cost of fighting but not the (generally unobservable) prize and therefore affect civil conflict risk if at least some conflicts are triggered by changes in the opportunity cost of participation. Estimation of the effect of transitory income shocks on civil conflict risk is still not fully understood however. In this paper I argue that the appropriate approach has to be tailored to the (lack of) persistence of the income shocks. The failure to do so may lead to the conclusion that adverse income shocks increase the risk of civil conflict which would seem to confirm the opportunity-cost effect - when they actu- 
ally lower civil conflict risk. I illustrate this point by revisiting Miguel et al.'s (2004) conclusion that adverse rainfall shocks and income shocks increase the risk of conflict in Subsaharan Africa. My empirical analysis reaches the opposite conclusion.

The remainder of the paper is structured as follows. Section 2 considers the direct effect of rainfall shocks on civil conflict risk, building extensively on Ciccone (2011). Section 3 contains the main analysis. I present two empirical approaches to estimate the effect of transitory income shocks on civil conflict using rainfall shocks as an instrument and illustrate the two approaches using Miguel et al.'s (2004) dataset.

\section{Rainfall and Civil Conflict}

Two different empirical approaches have been used in the literature to examine the direct effect of rainfall on civil conflict risk. One approach relates civil conflict risk to year-on-year rainfall growth rates while the other relates conflict risk to rainfall levels. I present the two approaches and discuss their advantages and disadvantage. Following Ciccone (2011) I conclude that the rainfall level approach is preferable if the objective is to identify the effect of rainfall shocks on conflict risk.

\subsection{Rainfall Growth Rates versus Rainfall Levels}

Miguel et al. (2004) and Miguel and Satyanath $(2010,2011)$ investigate the effect of rainfall on the risk of civil conflict by relating civil conflict risk in country $c$ and year $t$ to year-on-year rainfall growth using the following (linear-probability) model

$$
\text { Conflict }_{c t}=\theta_{c}+\gamma_{c} t+\beta_{0} \text { RainGrowth }_{c t}+\beta_{1} \text { RainGrowth }_{c t-1}+u_{c t} .
$$

Conflict $_{c t}$ is a $0 / 1$ variable capturing whether a civil conflict started in year $t$ or alternatively whether there was a conflict in year $t$. Year $t$ rainfall growth refers to the growth rate of annual rainfall between year $t$ and $t-1$. The country specific trend $\theta_{c}+\gamma_{c} t$ is meant to capture that conflict is more likely in some countries for a variety of (difficult to observe) reasons and that conflict risk may evolve differently across countries. Other factors affecting the risk of civil conflict are captured by the residual $u_{c t}$. Using the log approximation for growth rates, RainGrowth ${ }_{c t}=\ln$ Rain $_{c t}-\ln$ Rain $_{c t-1}$, (1) can be written as

Conflict $_{c t}=\theta_{c}+\gamma_{c} t+\beta_{0}\left(\ln\right.$ Rain $_{c t}-\ln$ Rain $\left._{c t-1}\right)+\beta_{1}\left(\ln\right.$ Rain $_{c t-1}-\ln$ Rain $\left._{c t-2}\right)+u_{c t}$.

A second approach relates civil conflict risk to how much it rained in different years instead of year-on-year rainfall growth. This approach is used in Ciccone (2011) who estimates

$$
\text { Conflict }_{c t}=\theta_{c}+\gamma_{c} t+\alpha_{0} \ln \text { Rain }_{c t}+\alpha_{1} \ln \text { Rain }_{c t-1}+\alpha_{2} \ln \text { Rain }_{c t-2}+u_{c t}
$$


where $\ln$ Rain $_{c t}$ denotes rainfall levels measured in log points.

Which approach is preferable? If the objective is descriptive, (2) is evidently preferable if one wants to describe the partial correlations between civil conflict risk and year-on-year rainfall growth rates at different lags, while (3) is preferable if one wants to describe the partial correlations between conflict risk and rainfall levels at different lags. If the objective is prediction or hypothesis testing, (3) is preferable as it is more general and encompasses (2) as a special case $\left(\alpha_{0}=\beta_{0}, \alpha_{1}=\beta_{1}-\beta_{0}\right.$, and $\left.\alpha_{2}=-\beta_{1}\right)$. Finally, if the objective is to determine the effect of unpredictable changes in rainfall (rainfall shocks) on civil conflict, (2) is preferable if rainfall levels follow a random walk, that is $\ln$ Rain $_{c t}=\ln \operatorname{Rain}_{c t-1}+\varepsilon_{c t}$ (rainfall shocks have permanent effects on rainfall levels). In this case $\beta_{0}$ and $\beta_{1}$ capture the effect of (permanent) rainfall shocks $\varepsilon_{c t}$ and $\varepsilon_{c t-1}$ on the risk of civil conflict. On the other hand, (3) is preferable if rainfall levels are mean reverting (rainfall shocks are transitory). Using (2) instead of (3) if rainfall levels are mean reverting can result in unwarranted conclusions about the effect of rainfall shocks on the risk of civil conflict.

\subsection{Identifying the Effect of Rainfall Shocks on Conflict}

Empirically, rainfall levels are strongly mean reverting. For example, estimating $\ln \operatorname{Rain}_{c t}=\delta_{c}+\rho \ln$ Rain $_{c t-1}+\nu_{c t}$ using the rainfall data for Subsaharan Africa in Miguel et al. (2004) yields a coefficient $\rho$ of 0.17. (If countryspecific linear trends are included, the coefficient $\rho$ is 0.04) $1^{1}$ Hence, rainfall shocks have only transitory effects on rainfall levels. To see why (3) is preferable to (2) when rainfall levels are mean reverting and rainfall shocks are transitory, suppose that deviations of rainfall from the long-run mean level are i.i.d.,

$$
\ln \operatorname{Rain}_{c t}=\overline{\ln \operatorname{Rain}_{c}}+R \text { Shock }_{c t}
$$

where $R S h o c k_{c t}$ stands for rainfall shocks in country $c$ and year $t$ (unpredictable deviations from long-run mean rainfall). In this case, the year-onyear growth rate of rainfall is $\ln$ Rain $_{c t}-\ln \operatorname{Rain}_{c t-1}=R S h o c k_{c t}-R S h o c k_{c t-1}$ and (2) becomes

Conflict $_{c t}=\theta_{c}+\gamma_{c} t+\beta_{0}\left(R_{S h o c k_{c t}}-\right.$ RShock $\left._{c t-1}\right)+\beta_{1}\left(\right.$ RShock $_{c t-1}-$ RShock $\left._{c t-2}\right)+u_{c t}$.

Hence, $\beta_{0}$ captures both the effect of positive rainfall shocks at $t$ and negative rainfall shocks at $t-1$. This is because year-on-year rainfall growth between $t$ and $t-1$ may be high because of (i) a positive rainfall shock at $t$ or (ii) a negative rainfall shock at $t-1$ (followed by mean reversion). The same issue applies to the interpretation of $\beta_{1}$. As a result, the rainfall growth approach cannot identify the effect of rainfall shocks on civil conflict risk.

1 See Miguel et al. (2004) for a comprehensive description of their rainfall data. 
On the other hand, substituting (4) into (3) yields

$$
\text { Conflict }_{c t}=\theta_{c}+\gamma_{c} t+\alpha_{0} R S h o c k_{c t}+\alpha_{1} \text { RShock }_{c t-1}+\alpha_{2} R S h o c k_{c t-2}+u_{c t}
$$

where the mean rainfall level $\overline{\ln \operatorname{Rain}_{c}}$ has been absorbed into $\theta_{c}$. Hence, $\alpha_{0}, \alpha_{1}$, and $\alpha_{2}$ capture the effect of current and past rainfall shocks on civil conflict risk.

Ciccone (2011) presents least-squares estimates for both the rainfall growth approach in (2) and the rainfall level approach in (3) using the data for Subsaharan Africa in Miguel et al. (2004). Table 1 reproduces his results using the rainfall level approach for conflict onset as well as conflict incidence. Conflict onset is a $0 / 1$ variable capturing whether a conflict started in year $t$ while conflict incidence is a $0 / 1$ variable capturing whether there is a (possibly ongoing) conflict in year $\left.t\right|^{2}$ In column (1) it can be seen that conflict onset at $t$ is significantly more likely if rainfall levels at $t-2$ are higher. Or put differently, positive (negative) rainfall shocks increase (decrease) the risk of civil conflict with a two-year lag. This is inconsistent with rainfall shocks affecting civil conflict risk through an opportunity-cost channel. Column (2) shows that negative rainfall shocks continue to lower civil conflict risk when the conflict incidence indicator is used. Note that this specification controls for lagged conflict incidence, as civil conflicts are persistent. Column (3) confirms the results in column (2) using a GMM approach. According to the point estimates in columns (1)-(3), a one-percentage-point decrease in rainfall lowers the risk of civil conflict two years later by between 0.12 and 0.16 percentage points. Columns (4)-(6) follow Miguel et al. (2004) and examine the link between civil conflict risk and year-on-year rainfall growth rates. This yields that civil conflict risk is significantly higher following low year-on-year rainfall growth at $t-1$. This should not be interpreted as conflict risk being higher following negative rainfall shocks however. As shown in columns (1)-(3), conflict risk is lower following negative rainfall shocks. As year-on-year rainfall growth tends to be high following negative rainfall shocks (because of mean reversion), the fact documented in columns (1)-(3) that conflict risk is lower following negative rainfall shocks at $t-2$ translates into a negative partial correlation between conflict risk and lagged year-onyear rainfall growth in the specifications in columns (4)-(6).

The conclusion in Table 1, columns (1)-(3) that lower (higher) rainfall levels lower (raise) the risk of civil conflict seems at odds with Miguel and Satyanath's $(2010,2011)$ findings that there is no statistically significant link between conflict risk and rainfall levels. There are two reasons for this discrepancy. First Miguel and Satyanath $(2010,2011)$ do not present results for civil conflict onset. Second their results for civil conflict incidence do not control for lagged conflict incidence.$^{3}$

2 See Miguel et al. (2004) for a comprehensive description of their conflict data.

${ }^{3}$ In fact Miguel and Satyanath's $(2010,2011)$ finding can be recovered by dropping the lagged civil conflict incidence indicator in Table 1, columns (2)-(3). 
Table 1: Rainfall and Civil Conflict Onset/Incidence

\begin{tabular}{|c|c|c|c|c|c|c|}
\hline & $\begin{array}{c}\text { (1) } \\
\text { onset } \\
\text { LS } \\
\end{array}$ & $\begin{array}{c}(2) \\
\text { incidence } \\
\text { LS } \\
\end{array}$ & $\begin{array}{c}\text { (3) } \\
\text { incidence } \\
\text { GMM } \\
\end{array}$ & $\begin{array}{c}\text { (4) } \\
\text { onset } \\
\text { LS } \\
\end{array}$ & $\begin{array}{c}\text { (5) } \\
\text { incidence } \\
\text { LS } \\
\end{array}$ & $\begin{array}{c}\text { (6) } \\
\text { incidence } \\
\text { GMM } \\
\end{array}$ \\
\hline Log Rainfall, t & $\begin{array}{l}-0,073 \\
(0.078) \\
{[0.086]}\end{array}$ & $\begin{array}{l}-0.053 \\
(0.068) \\
{[0.066]}\end{array}$ & $\begin{array}{l}-0.033 \\
(0.063)\end{array}$ & & & \\
\hline Log Rainfall, t-1 & $\begin{array}{l}-0,026 \\
(0.069) \\
{[0.075]}\end{array}$ & $\begin{array}{l}-0.102 \\
(0.069) \\
{[0.075]}\end{array}$ & $\begin{array}{c}-0.094 \\
(0.066)\end{array}$ & & & \\
\hline Log Rainfall, t-2 & $\begin{array}{l}0.156 * * \\
(0.068) \\
{[0.074]}\end{array}$ & $\begin{array}{l}0.128 * \\
(0.067) \\
{[0.072]}\end{array}$ & $\begin{array}{l}0.125 * \\
(0.064)\end{array}$ & & & \\
\hline Rainfall Growth, $\mathrm{t}$ & & & & $\begin{array}{l}-0,063 \\
(0.044) \\
{[0.048]}\end{array}$ & $\begin{array}{l}-0,025 \\
(0.042) \\
{[0.043]}\end{array}$ & $\begin{array}{c}-0,017 \\
(0.043)\end{array}$ \\
\hline Rainfall Growth, $\mathrm{t}$ & & & & $\begin{array}{c}-0.120 * \\
(0.062) \\
{[0.068]}\end{array}$ & $\begin{array}{c}-0.129 * * \\
(0.048) \\
{[0.051]}\end{array}$ & $\begin{array}{c}-0.123 * * \\
(0.049)\end{array}$ \\
\hline Lagged Incidence & & $\begin{array}{l}0.274 * * * \\
(0.078) \\
{[0.082]}\end{array}$ & $\begin{array}{c}0.280 * * * \\
(0.078)\end{array}$ & & $\begin{array}{c}0.277 * * * \\
(0.077) \\
{[0.083]}\end{array}$ & $\begin{array}{c}0.282 * * * \\
(0.077)\end{array}$ \\
\hline $\begin{array}{l}\text { Country FE } \\
\text { Country Trend } \\
\text { Observations }\end{array}$ & $\begin{array}{l}\text { yes } \\
\text { yes } \\
555\end{array}$ & $\begin{array}{l}\text { yes } \\
\text { yes } \\
743\end{array}$ & $\begin{array}{l}\text { yes } \\
\text { yes } \\
743\end{array}$ & $\begin{array}{l}\text { yes } \\
\text { yes } \\
555\end{array}$ & $\begin{array}{l}\text { yes } \\
\text { yes } \\
743\end{array}$ & $\begin{array}{l}\text { yes } \\
\text { yes } \\
743\end{array}$ \\
\hline
\end{tabular}

Note: The left-hand-side variable is an indicator variable capturing civil conflict incidence. The method of estimation is least squares or system-GMM. Standard errors in parentheses are robust for arbitrary heteroskedasticity and clustered at the country level. Standard errors in square brackets also apply the STATA small-sample adjustment preferred by Miguel and Satyanath $(2010,2011)$. The statistical theory behind hypothesis tests using the small- sample-adjusted standard errors assumes normally distributed and homoskedastic residuals (e.g. Greene, 1990, page 161). Both the normality assumption and the homoskedasticity assumption are violated in linear probability models, where the left-hand-side variable is either 0 or 1 as in the case of civil conflict onset and incidence (e.g. Wooldridge, 2002, page 454). I report standard errors incorporating the small-sample adjustment to facilitate comparison with Miguel and Satyanath $(2010,2011)$. *Significantly different from zero at 90 percent confidence, ** 95 percent confidence, ${ }^{* * *} 99$ percent confidence. 


\section{Income Shocks and Civil Conflict}

There is a by now sizable literature in political science and economics on the effect of income on civil conflict risk (e.g. Collier and Hoeffler, 1998; Fearon and Laitin, 2003; Miguel et al. 2004; Hegre and Sambanis, 2006; Djankov and Reynal-Querol, 2010). A strand of this literature has focused on identifying causal effects of income shocks on conflict risk (e.g. Miguel et al. 2004; Bruckner and Ciccone, 2010; Bruckner et al. 2012). Because of feedback from civil conflict risk to income, this requires an instrumentalvariables approach. The main variables used as instruments so far are international commodity prices and rainfall, as these variables can be expected to have a causal (first-stage) effect on income in countries that rely on commodity exports and/or rainfed agriculture. As is well understood, international commodity prices and rainfall must affect civil conflict risk only through income for instrumental-variables estimates to have a causal interpretation.

A less well understood issue is that the appropriate instrumental-variables approach when estimating the effect of income shocks on civil conflict risk depends on whether the instrument has transitory or permanent effects on income. To see this point, consider the instrumental-variables approach of Miguel et al. (2004). They estimate the following (linear probability) model

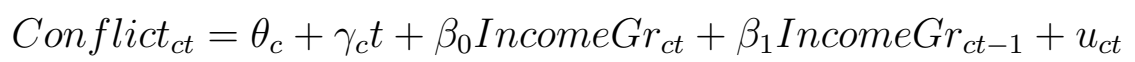

where Income $G r_{c t}$ is the growth rate of income between $t$ and $t-1$. Current and lagged income growth rates are instrumented with current and

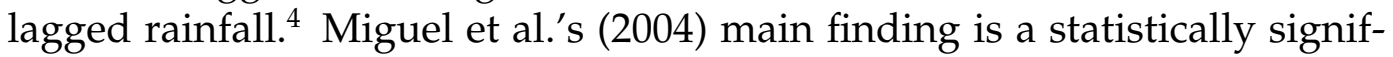
icant, negative effect of lagged income growth on civil conflict risk. They interpret this as evidence that negative income shocks increase the risk of civil conflict, which suggests that income shocks might affect civil conflict risk through an opportunity-cost channel.

But if rainfall shocks are transitory and have a transitory effect on income, Miguel et al.'s (2004) interpretation of their results may be unwarranted. In this case, income growth between $t$ and $t-1$ may be high because of (i) a transitory, positive income shock at $t$ driven by a positive rainfall shock or (ii) a transitory, negative income shock at $t-1$ driven by a negative rainfall shock (followed by mean reversion). If high income growth rates are sometimes due to mean reversion, the approach in (7) might produce a negative effect of income growth on civil conflict risk although civil conflict risk actually falls following negative (transitory) income shocks. To see whether this issue may be relevant in empirical practice, I first examine

${ }_{4}^{4}$ The instruments used are current and lagged year-on-year rainfall growth rates. The issues discussed here would remain the same using current and lagged rainfall level instruments instead however. 
if rainfall shocks have transitory or permanent effects on income in Miguel et al.'s (2004) data. As the evidence indicates transitory effects, I present two instrumental-variables approaches to estimate the effect of transitory income shocks on civil conflict risk. Both approaches suggest that civil conflict in Miguel et al.'s data is less likely following transitory, negative income shocks.

\subsection{Do Rainfall Shocks Have Transitory Effects on Income?}

In principle, transitory rainfall shocks can have transitory or long-lasting (permanent) effects on income. To examine this issue, I follow Dell et al. (2012) and estimate

$$
\ln y_{c t}-\ln y_{c t-1}=\delta_{c}+\sum_{l=0}^{L} \delta_{l} \ln \operatorname{Rain}_{c t-l}+u_{c t}
$$

with least squares. This formulation implies that a one-percentage-point increase in rainfall raises income after $L$ years by $\delta_{0}+\delta_{1}+\ldots+\delta_{L}$ percentage points. Estimating (8) with Miguel et al.'s (2004) data yields 5

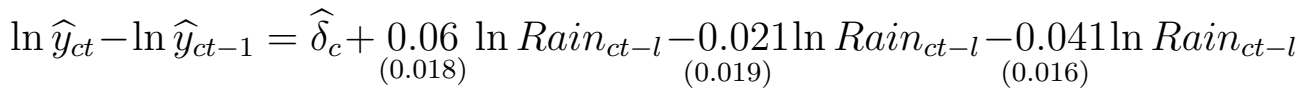

where $\ln \widehat{y}_{c t}-\ln \widehat{y}_{c t-1}$ denotes the predicted growth rate of income; $\widehat{\delta}_{c}$ denotes estimated country-specific intercepts; and the numbers in parentheses are robust standard errors clustered at the country level..$^{6}$ It can be seen that rainfall shock have a highly statistically significant, positive contemporaneous effect on income growth. A one-percentage-point increase in rainfall increases income growth by 0.06 percentage point on impact. But - because of mean reversion - lagged rainfall shocks have a negative effect on income growth. As a result, a positive rainfall shock only increases income growth by $0.039(0.06-0.021)$ percentage points after one year and by $-0.002(0.06-$ 0.021-0.041) percentage points after two years. The hypothesis that rainfall shocks do not affect income after two years cannot be rejected at any conventional confidence level. Hence, positive rainfall shocks have a positive but transitory effect on income.

\subsection{Estimating Transitory Income Shocks and Their Effect on Civil Conflict Risk}

As rainfall has a transitory effect on income, rainfall fluctuations can be used as an instrument to estimate the effect of transitory (but not permanent) income shocks on the risk of civil conflict. I now present two

\footnotetext{
5 See Miguel et al. (2004) for a comprehensive description of their rainfall and income data.

${ }^{6}$ Results are similar when I also control for country-specific linear time trends. In this case the rainfall coefficients (standard errors) are $0.058(0.018),-0.019(0.021)$, and -0.035 (0.017).
} 
instrumental-variable approaches to estimate the effect of transitory income shocks on civil conflict risk. The two approaches differ in the way they deal with income trends.

\subsubsection{Detrending Income with a Linear Trend}

In the simplest model of income dynamics, log income is given by stationary fluctuations around a deterministic, linear trend

$$
\ln y_{c t}=\eta_{c}+\lambda_{c} t+\varepsilon_{c t}
$$

where $\varepsilon_{c t}$ captures transitory income shocks, including those due to rainfall shocks. The main question of interest is whether the transitory income shocks $\varepsilon_{c t}$ affect the risk of civil conflict. This question can be addressed by estimating

$$
\text { Conflict }_{c t}=\theta_{c}+\gamma_{c} t+\alpha_{0} \varepsilon_{c t}+\alpha_{1} \varepsilon_{c t-1}+\alpha_{2} \varepsilon_{c t-2}+u_{c t} .
$$

While transitory income shocks are not directly observable, they can be backed out from (10) as $\varepsilon_{c t}=\ln y_{c t}-\left(\eta_{c}+\lambda_{c} t\right)$. Substituting this expression in (11) and collecting terms yields

$$
\text { Conflict } \left._{c t}=a_{c}+b_{c} t+\alpha_{0} \ln y_{c t}+\alpha_{1} \ln y_{c t-1}+\alpha_{2} \ln y_{c t-2}+u_{c t}\right]^{7}
$$

The main empirical challenge in estimating (12) is that (changes in) civil conflict risk may feed back into income. To obtain consistent estimates of the effect of transitory income shocks on civil conflict risk, I therefore instrument income by contemporaneous rainfall. 8

\subsubsection{Detrending Income with the Hodrick and Prescott Filter}

Taking the income trend to be linear is quite restrictive. Modern macroeconomics therefore uses the Hodrick and Prescott filter to remove income trends (e.g. Ravn and Uhlig, 2002). In this case, the effect of transitory income shocks on civil conflict risk cannot be estimated in a single step as in (12). Two steps are necessary. The first step detrends income with the Hodrick and Prescott filter and obtains transitory income shocks $\widehat{\varepsilon}_{c t}$ as the difference between actual income and the estimated income trend. The second step estimates

$$
\text { Conflict }_{c t}=\alpha_{c}+\gamma_{c} t+\alpha_{0} \widehat{\varepsilon}_{c t}+\alpha_{1} \widehat{\varepsilon}_{c t-1}+\alpha_{2} \widehat{\varepsilon}_{c t-2}+u_{c t}
$$

using rainfall as an instrument for estimated transitory income shocks $\widehat{\varepsilon}_{c t} \stackrel{9}{9}^{9}$

7 The country-specific linear trend in (12) is a combination of $\theta_{c}+\gamma_{c} t$ and $\eta_{c}+\lambda_{c} t$.

8 More precisely, each log income level on the right-hand side of (12) is instrumented by the corresponding contemporaneous log rainfall level. Hence, the set of instruments is $\ln$ Rain $_{c t}, \ln$ Rain $_{c t-1}$, and $\ln$ Rain $_{c t-2}$.

9 Regressing the income shocks $\widehat{\varepsilon}_{c t}$ obtained with the Hodrick and Prescott filter on current and lagged log rainfall levels yields least-squares coefficients of 0.033 and 0.034 respec- 
Table 2 - Income Shocks and Civil Conflict Onset/Incidence

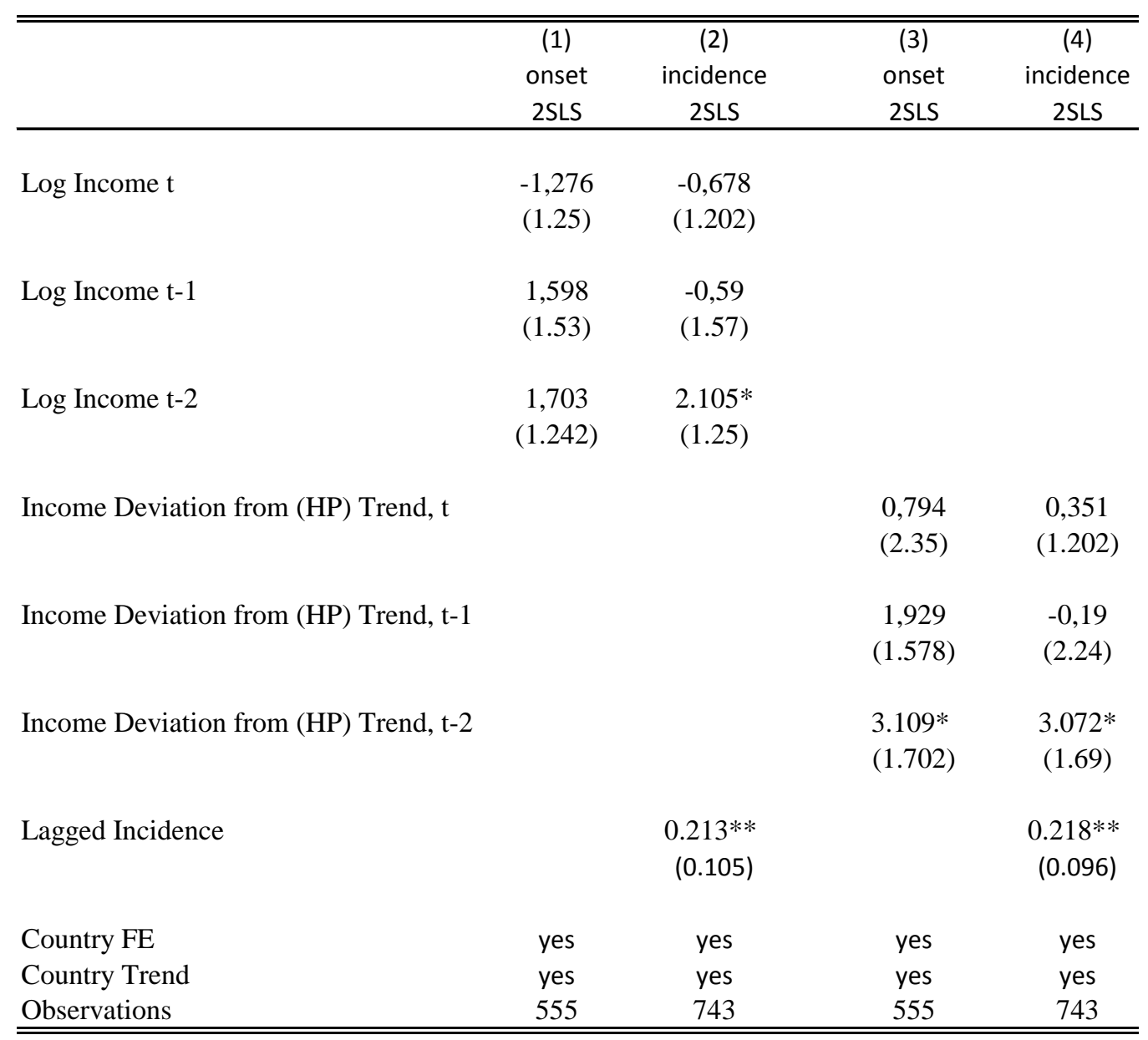

Note: The method of estimation is two-stage least squares. Standard errors in parentheses are robust for arbitrary heteroskedasticity and clustered at the country level. *Significantly different from zero at 90 percent confidence, ** 95 percent confidence, ${ }^{* \star *} 99$ percent confidence.

\subsection{Do Negative, Transitory Income Shocks Raise Civil Con- flict Risk?}

I now use the two instrumental-variables approaches to estimate the effect of (transitory) income shocks on civil conflict risk with the Miguel et al.'s (2004) data.

The results in Table 2, columns (1)-(2) are based on (12) and hence assume a linear income trend. The method of estimation is 2SLS using $\ln R a i n_{c t}$, $\ln$ Rain $_{c t-1}$, and $\ln$ Rain $_{c t-2}$ as instruments. The reported standard errors are robust for arbitrary heteroskedasticity and clustered at the country level. Results in column (1) measure civil conflict using the conflict onset indica-

tively. The corresponding robust standard errors clustered at the country level are 0.011 and 0.013 . Hence, current and lagged rainfall are highly statistically significant determinants of the income shocks obtained with the Hodrick and Prescott filter. Further rainfall lags enter statistically insignificantly. 
tor and results in column (2) using the conflict incidence indicator. Using the civil conflict onset indicator, there is no statistically significant relationship between transitory income shocks and civil conflict risk. But using the conflict incidence indicator, I find that negative income shocks lower civil conflict risk with a two-year lag. The effect is sizable. According to the point estimate in column (2), a one-percent increase in income raises civil conflict risk two years later by more than 2 percentage points. This finding stands in contrast with Miguel et al.' (2004) conclusion that negative income shocks raise civil conflict risk.

The results in Table 2, columns (3)-(4) are based on (13) with income detrended using a Hodrick-Prescott filter. As the data is annual, I follow Ravn and Uhlig (2002) and use a filter parameter value of 6.25. The method used to estimate (13) is 2SLS with $\ln$ Rain $_{c t}$, $\ln$ Rain $_{c t-1}$, and $\ln R a i n_{c t-2}$ as instruments. The reported standard errors are robust for arbitrary heteroskedasticity and clustered at the country level. ${ }^{10}$ Results in column (3) measure civil conflict using the conflict onset indicator and results in column (4) using the conflict incidence indicator. The empirical results indicate that negative, transitory income shocks lower civil conflict risk with a two-year lag, whether I use the civil conflict onset indicator or the civil conflict incidence indicator. The effect is again quite large. According to the point estimates in columns (3) and (4), a one-percent increase in income raises civil conflict risk two years later by more than 3 percentage points.

The empirical results in Table 2 indicate that, if anything, negative income shocks lower the risk of civil conflict in Subsaharan Africa. I reach a different conclusion than Miguel et al. (2004) because my empirical approach takes into account that rainfall has a transitory effect on income. This implies that an instrumental-variables strategy to estimate the effect of income shocks on civil conflict risk based on rainfall can at best estimate the effect of transitory income shocks. It also implies that year-on-year income growth rates cannot be used as measures of income shocks, as income growth may be low because of contemporaneous negative transitory income shocks or because of mean reversion following positive transitory income shocks. My finding that transitory negative income shocks do not increase civil conflict risk is inconsistent with transitory income shocks affecting civil conflict risk through an opportunity-cost channel.

\section{Conclusion}

Economists and political scientists have argued that differences in the risk of civil conflict across countries and over time may be partly driven by differences in the opportunity cost of participating in civil conflicts. As

${ }^{10}$ Even though the regressors of interest are estimated, the 2SLS approach yields standard errors that are valid for testing the null hypothesis of no effect (see Wooldridge, 2002, Section 6.1.2). 
made clear by Chassang and Miquel's (2009) theoretical analysis, one way to test for the opportunity-cost effect is to examine civil conflict risk following (transitory) shocks that affect contemporaneous but not long-run productivity, as such shocks should change the opportunity cost of fighting but not the (generally unobservable) prize. Estimation of the effect of transitory income shocks on civil conflict risk is still not fully understood however. I argue that the appropriate approach has to be tailored to the (lack of) persistence of the income shocks. The failure to do so may lead to the conclusion that adverse income shocks increase the risk of civil conflict - which would seem consistent with an opportunity-cost channel - when they actually lower civil conflict risk. I illustrate this point by revisiting Miguel et al.'s (2004) conclusion that negative income shocks increase the risk of conflict in Subsaharan Africa. I conclude that negative, transitory income shocks lower the risk of civil conflict. 


\section{References}

Bruckner, M., Ciccone, A., 2010. International Commodity Prices, Growth and the Outbreak of Civil War in Sub-Saharan Africa. Economic Journal 120, 519-534. doi:10.1111/j.1468-0297.2010.02353.x

Bruckner, M., Ciccone, A., Tesei, A., 2012. Oil, Income, and Democracy. Review of Economics and Statistics 94, 389-399. doi:10.1162/REST_a_00201

Buhaug, H., 2010. Climate Not to Blame for African Civil Wars. Proceedings of the National Academy of Sciences of the USA 107, 16477-16482. doi:10.1073/pnas.1005739107

Burke, M.B., Miguel, E., Satyanath, S., Dykema, J.A., Lobell, D.B., 2009. Warming Increases the Risk of Civil War in Africa. Proceedings of the National Academy of Sciences of the USA 106, 20670-20674. doi:10.1073/pnas.0907998106

Chassang, S., Miquel, G.P. i., 2009. Economic Shocks and Civil War. Quarterly Journal of Political Science 4, 211-228. doi:10.1561/100.00008072

Ciccone, A., 2011. Economic Shocks and Civil Conflict: A Comment. American Economic Journal: Applied Economics 3, 215-227. doi:10.1257/app.3.4.215

Collier, P., Hoeffler, A., 1998. On Economic Causes of Civil War. Oxford Economic Papers 50, 563-573. doi:10.1093/oep/50.4.563

Dell, M., Jones, B., Olken, B., 2012. Climate Shocks and Economic Growth: Evidence from the Last Half Century. American Economic Journal: Macroeconomics 4, 66-95. doi:10.1257/mac.4.3.66

Djankov, S., Reynal-Querol, M., 2010. Poverty and Civil War: Revisiting the Evidence. The Review of Economics and Statistics 92, 1035-1041. doi:10.1162/REST_a_00046

Greene, W.H., 1990. Econometric Analysis. Macmillan, New York, NY.

Fearon, J.D., 2007. Economic Development, Insurgency, and Civil War. In Helpman, E., (Ed.), Institutions and Economic Performance, Harvard University Press, Cambridge, MA. pp. 292-328.

Fearon, J.D., Laitin, D.D., 2003. Ethnicity, Insurgency, and Civil War. American Political Science Review 97, 75-90. doi:10.1017/S0003055403000534

Hegre, H., Sambanis, N., 2006. Sensitivity Analysis of Empirical Results on Civil War Onset. Journal of Conflict Resolution 50, 508-535. doi:10.1177/0022002706289303 
Hsiang, S.M., Meng, K.C., Cane, M.A., 2011. Civil Conflicts are Associated with the Global Climate. Nature 476, 438-441. doi:10.1038/nature10311

Miguel, E., Satyanath, S., Sergenti, E., 2004. Economic Shocks and Civil Conflict: An Instrumental Variables Approach. Journal of Political Economy 112, 725-753. doi:10.1086/421174

Miguel, E., Satyanath, S., 2010. Understanding Transitory Rainfall Shocks, Economic Growth and Civil Conflict. National Bureau of Economic Research Working Paper No. 16461.

Miguel, E., Satyanath, S., 2011. Re-examining Economic Shocks and Civil Conflict: A Comment. American Economic Journal: Applied Economics 3, 228-234. doi:10.1257/app.3.4.228

Ravn, M.O., Uhlig, H., 2002. On Adjusting the Hodrick-Prescott Filter for the Frequency of Observations. Review of Economic and Statistics 84, 371376. doi:10.1162/003465302317411604

Wooldridge, J.M., 2002. Econometric Analysis of Cross Section and Panel Data. MIT Press, Cambridge, MA. 